\title{
EFFECTS OF CRYOPRESERVATION ON CONTRACTILE PROPERTIES OF PORCINE ISOLATED AORTIC VALVE LEAFLETS AND AORTIC WALL
}

Claes Wassenaar, $\mathrm{MD}, \mathrm{PhD}^{\mathrm{a}}$ Willem A. Bax, $\mathrm{PhD}^{\mathrm{b}}$

Robert-Jan van Suylen, $\mathrm{MD}^{c}$

Voijslav D. Vuzevski, MD, $\mathrm{PhD}^{\mathrm{c}}$

Egbert Bos, MD, $\mathrm{PhD}^{\mathrm{d}}$
Human semilunar donor heart valves can be stored in banks, awaiting transplantation. To evaluate the result of the preservation protocols, a quantitative description of the tissue is necessary. In this study we investigated in a quantitative way the contractile properties of fresh and cryopreserved porcine isolated aortic heart valve leaflets in response to a number of endogenous vasoactive compounds. The responses of strips of the aortic wall were included for comparison. Contraction was measured isometrically in response to potassium $\left(\mathrm{K}^{+} ; 100 \mathrm{mmol} / \mathrm{L}\right)$, 5-hydroxytryptamine $(1 \mathrm{nmol} / \mathrm{L}$ to $100 \mu \mathrm{mol} / \mathrm{L})$, noradrenaline $(1 \mathrm{nmol} / \mathrm{L}$ to $100 \mu \mathrm{mol} / \mathrm{L})$, endothelin-1 $(0.01 \mathrm{nmol} / \mathrm{L}$ to $0.3 \mu \mathrm{mol} / \mathrm{L})$, and prostaglandin $F_{2 \alpha}(0.1$ $\mathrm{nmol} / \mathrm{L}$ to $10 \mu \mathrm{mol} / \mathrm{L}$ ). The pharmacologic parameters $\mathrm{E}_{\mathrm{MAX}}$ (the maximal response expressed as a percentage of contraction to a $100 \mathrm{mmol} / \mathrm{L}$ dose of $\mathrm{K}^{+}$) and $\mathrm{EC}_{50}$ (the concentration that produces $50 \%$ of the maximal effect) were calculated for every compound ( $n=6$ to 7 each). We observed that all specimens contracted in response to potassium. Its magnitude in fresh leaflets equaled $1.6 \pm 0.14 \mathrm{mN}$ compared with $26.6 \pm 2.6 \mathrm{mN}$ in fresh aortic wall. Noradrenaline, endothelin-1, and prostaglandin $F_{2 \alpha}$ all caused contraction in valvular leaflets and aortic wall, whereas 5-hydroxytryptamine caused contraction in the valvular leaflets but relaxation in aortic wall. After cryopreservation, the response to $\mathrm{K}^{+}$amounted to $24 \%$ of the response of the fresh specimens in valvular leaflets $(n=25)$ and $14 \%$ in aortic wall $(n=26)$. The values of $\mathrm{E}_{\mathrm{MAX}}$ and $\mathrm{EC}_{50}$ of the responses to noradrenaline, endothelin-1, and prostaglandin $F_{2 \alpha}$ remained unchanged. Although the physiologic relevance of contraction of valvular leaflets needs further study, its measurement may provide an additional model to verify the consequences of alternative methods of preservation. ( $J$ Thorac Cardiovasc Surg 1997;113:165-72)
$R_{b}^{\mathrm{c}}$ eplacement of diseased human semilunar valves by human donor valves is a standardized technique in cardiac surgery. ${ }^{1,2}$ Preservation techniques, such as controlled-rate freezing, have allowed for the development of valve banks. However, the rela-

From the Heart Valve Bank Rotterdam, University Hospital Rotterdam, ${ }^{a}$ the Departments of Pharmacology ${ }^{b}$ and Pathology, ${ }^{\mathrm{C}}$ Erasmus University Rotterdam, and the Department of Cardio-Pulmonary Surgery, University Hospital Rotterdam, ${ }^{\mathrm{d}}$ Rotterdam, The Netherlands.

Received for publication Jan. 22, 1996; revisions requested March 11, 1996; revisions received August 1, 1996; accepted for publication August 1, 1996.

Address for reprints: C. Wassenaar, MD, PhD, Heart Valve Bank Rotterdam, University Hospital Rotterdam, Dr. Molewaterplein 40, 3015 GD Rotterdam, The Netherlands.

Copyright (C) 1997 by Mosby-Year Book, Inc.

$0022-5223 / 97 \$ 5.00+0 \quad 12 / 1 / 77138$ tion between preservation methods and clinical follow-up data is not consistent. ${ }^{3}$ A number of factors, such as the type of valve donor (beating heart versus cadaveric) or the interval between the arrest of the donor heart and preservation of the valves, ${ }^{4,5}$ may influence tissue quality even before the start of any preservation technique. Consequently the term cryopreserved valve is only a partial description of a donor valve. Quantitative determinants of the presence and function of the cells in the valve just before implantation are therefore essential to characterize an allograft more completely.

The matrix-synthesizing capacity of the valve leaflet fibroblast has been used to monitor in a quantitative way the effects of preservation techniques. ${ }^{6-10}$ More recently, contractile properties of valve leaflet interstitial cells have been noticed. ${ }^{11,12}$ In this study we investigated in a quantitative way the contraction 


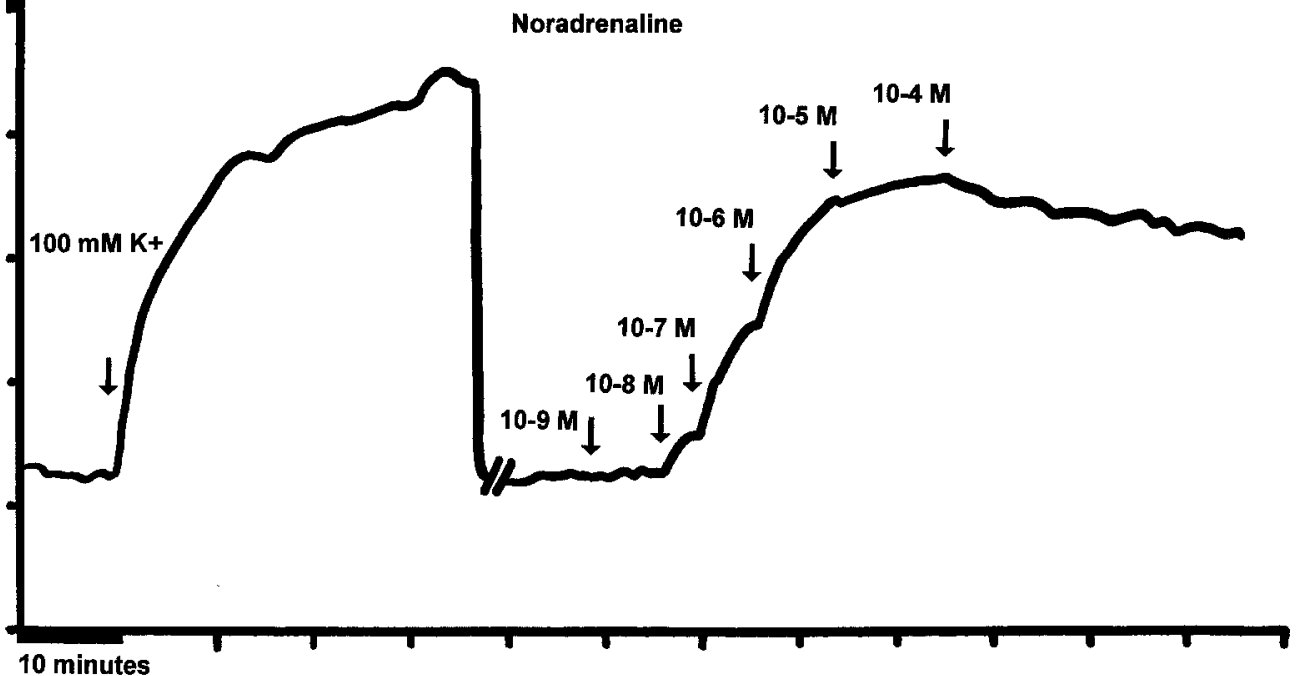

Fig. 1. Example of tracing of contractile response of porcine aortic leaflet to single dose of $100 \mathrm{mmol} / \mathrm{L}$ $\mathrm{K}^{+}$and to increasing concentrations of noradrenaline.

of isolated fresh porcine aortic leaflets in response to a number of pharmacologic vasoactive compounds. We compared the effect on valve leaflets with the response obtained in adjacent strips of aortic wall. Additionally, we studied the effects of cryopreservation as used for transplantation purposes on the response to these compounds. Although the physiologic role of contraction and relaxation of semilunar valves may yet be unclear, changes in this capacity may serve as an additional tool to monitor the effect of different preservation and processing techniques.

\section{Methods}

Procurement of tissues. Porcine hearts were obtained at a local slaughterhouse and dissected within 2 hours after circulatory arrest. After removal of the aortic valve from the heart, the complete left or right coronary cusp was removed from the anulus. The basal side of the leaflet was trimmed to obtain a rectangular, circumferentially oriented strip of about $8 \times 15 \mathrm{~mm}$. A transversal sample of $4 \times 15 \mathrm{~mm}$ was taken from the aortic wall. These ("fresh") leaflet and aortic wall specimens were tested immediately for the contractile and relaxing response to several compounds (see further). The remaining aortic valve was processed in accordance with procedures for our human material. ${ }^{13}$ This included incubation in a low-dose antibiotic cocktail for 24 hours at $4^{\circ} \mathrm{C}$ and cryopreservation in Tc 199 medium, containing 10\% dimethyl sulfox- ide, at a freezing rate of $1^{\circ} \mathrm{C}$ per minute. Valves were stored at $-150^{\circ} \mathrm{C}$. After 1 to 3 weeks, the cryopreserved valves were thawed in a $40^{\circ} \mathrm{C}$ water bath, followed by stepwise dilution of dimethyl sulfoxide. Again, one leaflet and a circular strip of the aortic vascular wall were excised and tested for their relaxing and contractile properties. After pharmacologic testing, the wet weight of the tissue samples was determined; thereafter, four samples were fixed for morphologic studies.

Pharmacologic studies. The relaxant and contractile properties of the fresh and cryopreserved tissue pieces were investigated in a $15 \mathrm{ml}$ organ bath containing oxygenated Krebs bicarbonate solution at a temperature of $37^{\circ} \mathrm{C}$. Composition of the Krebs solution was as follows: $118 \mathrm{mmol} / \mathrm{L} \mathrm{NaCl}, 4.7 \mathrm{mmol} / \mathrm{L} \mathrm{KCl}, 2.5 \mathrm{mmol} / \mathrm{L} \mathrm{CaCl}_{2}, 1.2$ $\mathrm{mmol} / \mathrm{L} \quad \mathrm{MgSO}_{4}, 1.2 \mathrm{mmol} / \mathrm{L} \quad \mathrm{KHPO}_{4}, 25 \mathrm{mmol} / \mathrm{L}$ $\mathrm{NaHCO}_{3}$, and $8.3 \mathrm{mmol} / \mathrm{L}$ glucose, with a pH of 7.4. Both ends of the tissue samples were tied to the tension transducer by means of 3-0 silk sutures. Preparations were stretched to a load of $3 \mathrm{mN}$ for the valve leaflets and 40 $\mathrm{mN}$ for the aortic strips, as assessed in pilot experiments. The tissues were allowed to stabilize in the tissue bath for 1 hour and were washed with Krebs bicarbonate solution every 15 minutes. Changes in isometric tension were measured with a Harvard isometric transducer and recorded on paper. The tissues were exposed to $30 \mathrm{mmol} / \mathrm{L}$ potassium twice before recording of the reference response evoked by $100 \mathrm{mmol} / \mathrm{L}$ potassium. After repeated washing, a cumulative concentration-response curve was obtained with one of the following compounds: 5-hydroxytryptamine $(5-\mathrm{HT} ; 1 \mathrm{nmol} / \mathrm{L}$ to $100 \mu \mathrm{mol} / \mathrm{L}$, Sigma Chem- 

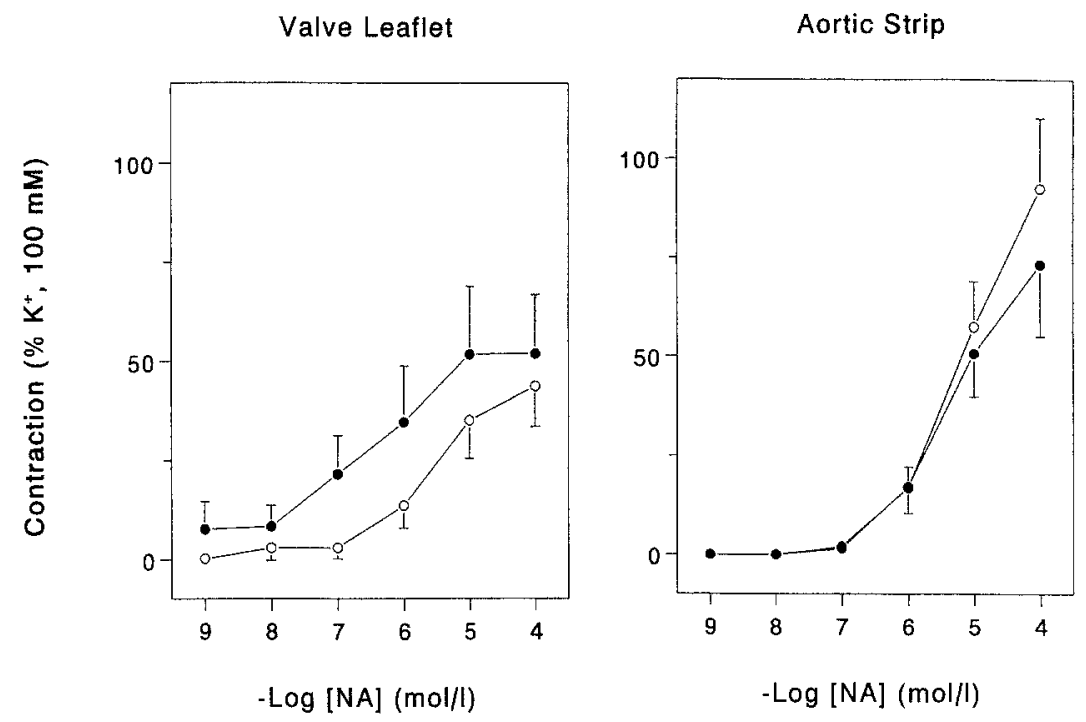

Fig. 2. Effect (plus or minus standard error of mean) of noradrenaline on isolated valve leaflets and aortic strips, before (open circles) and after (solid circles) cryopreservation ( $n=6$ to 7 ). Effect is expressed as percentage of contraction to $100 \mathrm{mmol} / \mathrm{L} \mathrm{K}^{+}$. Concentration of noradrenaline refers to molars per liter.

ical Co., St. Louis, Mo.), noradrenaline $(1 \mathrm{nmol} / \mathrm{L}$ to 100 $\mu \mathrm{mol} / \mathrm{L}$, Sigma Chemical Co.), endothelin-1 (ET-1; 0.01 $\mathrm{nmol} / \mathrm{L}$ to $0.3 \mu \mathrm{mol} / \mathrm{L}$, Neosystem S.A., Strasbourg, France), and prostaglandin $\mathrm{F}_{2 \alpha}\left(\mathrm{PGF}_{2 \alpha} ; 0.1 \mathrm{nmol} / \mathrm{L}\right.$ to 10 $\mu \mathrm{mol} / \mathrm{L}$, Sigma Chemical Co.). Both the fresh and the cryopreserved sets of leaflet and vascular wall samples were tested for their response to a single compound.

Data analysis. The responses to 5-HT, noradrenaline, ET-1, and PGF $_{2 \alpha}$ were expressed as a percentage of the response to $100 \mathrm{mmol} / \mathrm{L}$ potassium. For each of these compounds the response was characterized by determination of the maximal contractile effect ( $\left.E_{\text {MAX }}\right)$ and the concentration that produces $50 \%$ of the maximal response $\left(\mathrm{EC}_{50}\right)$. The $\mathrm{EC}_{50}$ was derived from the calculated best fit curve. ${ }^{14}$ In some cases the maximal effect was not reached at the highest concentration tested, and an $\mathrm{EC}_{50}$ value could therefore not be calculated. Differences between the group averages of the fresh and cryopreserved valve leaflets and aortic wall strips were tested with the $t$ test (for paired values where appropriate). Correlation coefficients were calculated according to Pearson's method.

Morphologic study. The valves were fixed in $4 \%$ buffered formaldehyde and embedded in paraffin. Radial sections of $5 \mu \mathrm{m}$ thickness were stained with hematoxylineosin stain. Immunohistochemistry testing was done on two sets of fresh and cryopreserved leaflets with monoclonal antibodies directed against smooth muscle cell $\alpha$-actin (DAKO). Another two sets of fresh and cryopreserved leaflets were analyzed by transmission electron microscopy for structural changes. These specimens were fixed in $2.5 \%$ glutaraldehyde and subsequently in $1 \%$ osmium tetroxide, dehydrated in graded acetones, and embedded in LX 112 resin (Merck, Darmstadt, Germany). Sections were cut to $40 \mathrm{~nm}$, stained with uranyl acetate and lead citrate and examined under a Zeiss EM 902 electron microscope at $80 \mathrm{kV}$. The extent of cellular injury was assessed according to Crescenzo and coworkers. ${ }^{15}$ Injury was judged to be reversible when cytoplasmic edema, dilation of the endoplasmic reticulum, or swelling of the mitochondria was present. Injury was considered irreversible in the presence of mitochondrial flocculent densities, karyolysis, or disruption of plasma membranes.

\section{Results}

Pharmacology. The contractile effect of 100 $\mathrm{mmol} / \mathrm{L} \mathrm{K}^{+}$was observed in all tissue samples (example in Fig. 1). A dose-dependent contraction of valve leaflets and aortic wall was observed for noradrenaline, ET-1, and $\mathrm{PGF}_{2 \alpha}$ (Figs. 2 to 4 ). However, 5-HT caused contraction in valve leaflets, but relaxation in aortic wall (Fig. 5). A weak correlation was found between the magnitude of the response after $100 \mathrm{mmol} / \mathrm{L} \mathrm{K}^{+}$and the sample weight (fresh leaflets: $n=25, r=0.15$; cryopreserved leaflets: $n=25, r=-0.35$; fresh aortic wall: $n=26, r=0.09$; cryopreserved aortic wall: $n=26$, $r=0.005$ ). In a comparison of the $\mathrm{E}_{\mathrm{MAx}}$ and $\mathrm{EC}_{50}$ values between leaflets and aortic wall, the largest differences were found for the $\mathrm{E}_{\text {MAX }}$ of 5-HT (84 vs $<-30, p=0.001)$ and the $\mathrm{EC}_{50}$ of $\mathrm{ET}-1$ (2.3 vs $>19$, $p=0.03$ ). Cryopreservation resulted in a reduction of the response to $100 \mathrm{mmol} / \mathrm{L} \mathrm{K}^{+}$from $1.61 \pm 0.14$ $\mathrm{mN}$ in fresh leaflets to $0.38 \pm 0.06 \mathrm{mN}(23.6 \%$ of the fresh response) in frozen leaflets $(p<0.0005)$. The response in aortic wall strips was $26.6 \pm 2.59 \mathrm{mN}$ in 

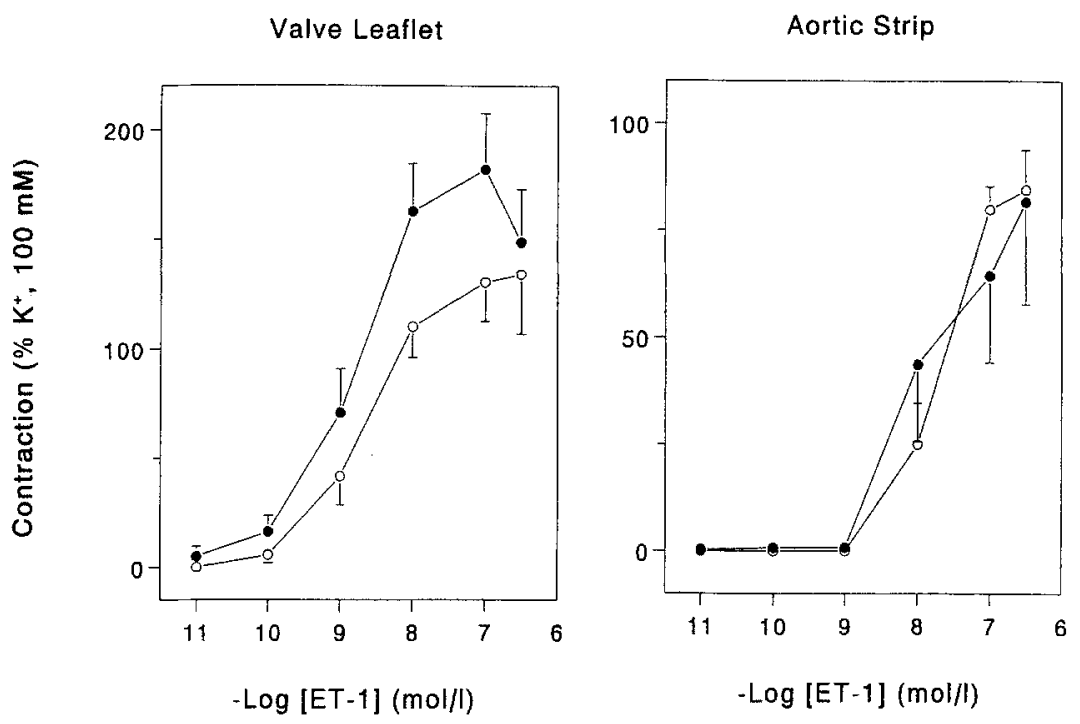

Fig. 3. Effect (plus or minus standard error of mean) of ET-1 on isolated valve leaflets and aortic strips, before (open circles) and after (closed circles) cryopreservation $(n=7)$. Effect is expressed as percentage of contraction to $100 \mathrm{mmol} / \mathrm{L} \mathrm{K}^{+}$. Concentration of ET-1 refers to molars per liter.
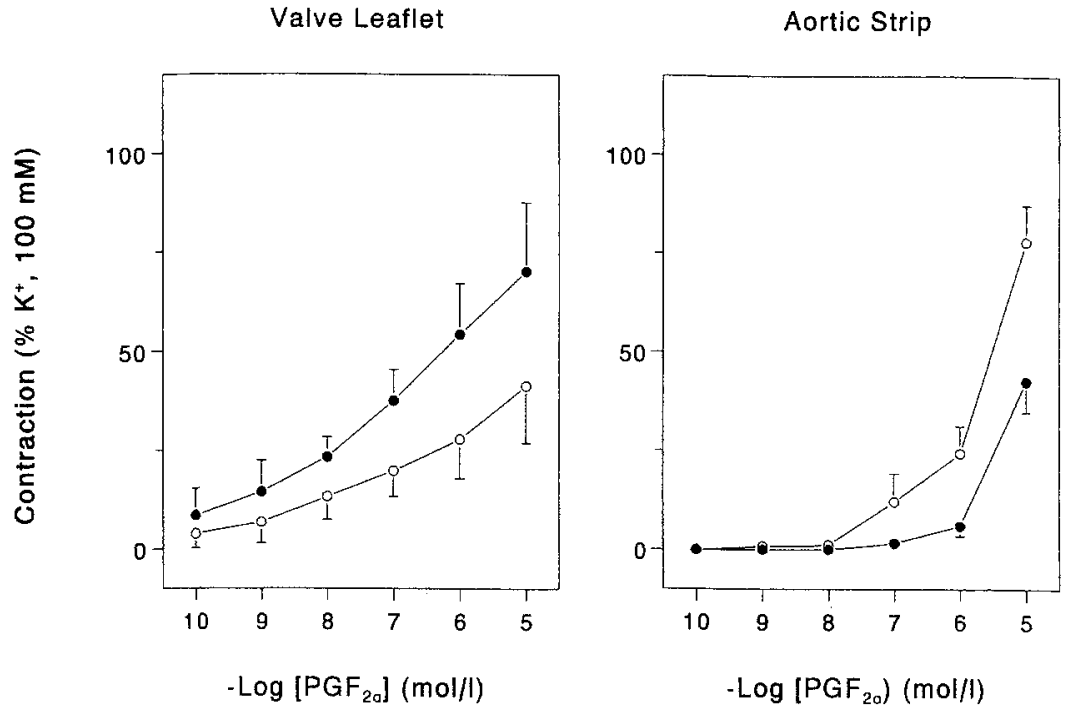

Fig. 4. Effect (plus or minus standard error of mean) of $\mathrm{PGF}_{2 \alpha}$ on isolated valve leaflets and aortic strips, before (open circles) and after (closed circles) cryopreservation ( $n=6$ to 7). Effect is expressed as percentage of contraction to $100 \mathrm{mmol} / \mathrm{L} \mathrm{K}^{+}$. Concentration of $\mathrm{PGF}_{2 \alpha}$ refers to molars per liter.

the fresh state and $3.63 \pm 0.55 \mathrm{mN}(13.6 \%$ of the fresh response) after freezing $(p<0.0005)$. Weak correlations were observed between the response to $100 \mathrm{mmol} / \mathrm{L} \mathrm{K}^{+}$before and after cryopreservation of valve leaflets $(r=0.06)$ and aortic wall $(r=-0.003)$. Cryopreservation reduced the response to 5-HT, noradrenaline, ET-1, and $\mathrm{PGF}_{2 \alpha}$ to a similar extent as it reduced the response to potassium. Therefore the calculated values of $\mathrm{E}_{\mathrm{MAX}}$ and $\mathrm{EC}_{50}$ for these compounds remained practically unchanged. These results are summarized in Table I.

Morphology. Light microscopy showed an intact architecture of the fresh and cryopreserved leaflets. The presence of $\alpha$-smooth muscle actin in a considerable number of cells in the leaflet was confirmed by immunohistochemistry. After cryopreservation 

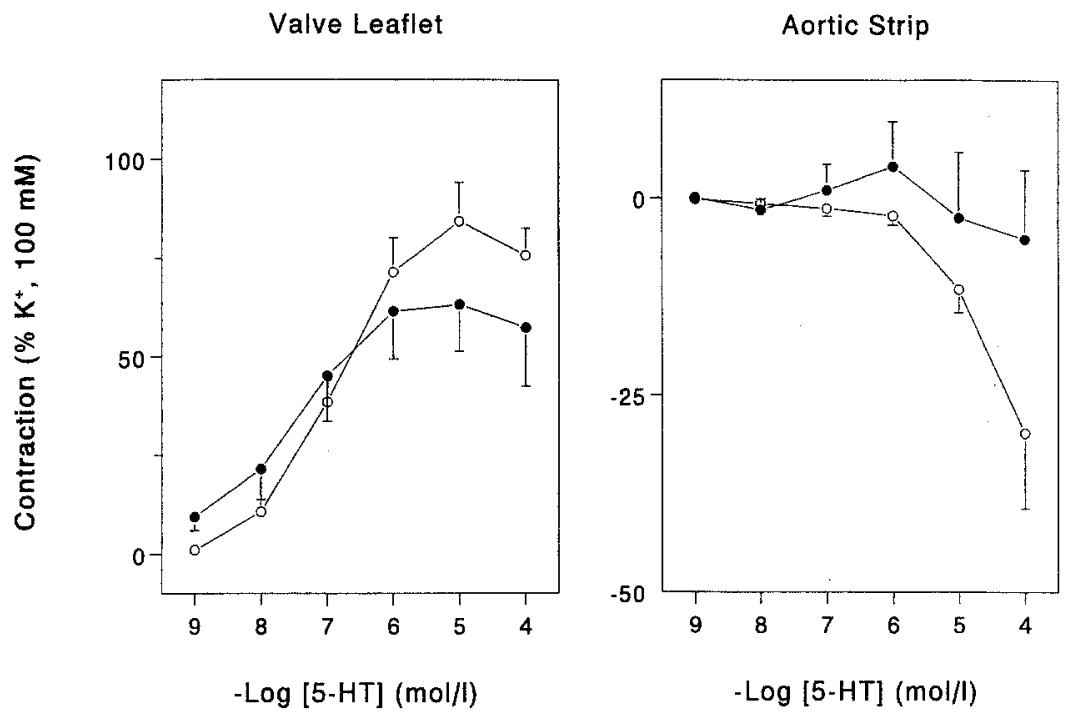

Fig. 5. Effect (plus or minus standard error of mean) of 5-HT on isolated valve leaflets and aortic strips, before (open circles) and after (solid circles) cryopreservation ( $n=6$ to 7). Effect is expressed as percentage of contraction to $100 \mathrm{mmol} / \mathrm{L} \mathrm{K}^{+}$. Concentration of 5-HT refers to molars per liter.

Table I. Contractile responses of fresh and cryopreserved tissues to a number of compounds

\begin{tabular}{|c|c|c|c|c|c|c|}
\hline & \multicolumn{3}{|c|}{$E C_{50}$} & \multicolumn{3}{|c|}{$E_{\text {MAX }}$} \\
\hline & Fresh & Cryopreserved & p Value & Fresh & Cryopreserved & $p$ Value \\
\hline \multicolumn{7}{|c|}{ Valve leaflets } \\
\hline 5-HT & $137 \pm 27 \mathrm{nmol} / \mathrm{L}$ & $81 \pm 40 \mathrm{nmol} / \mathrm{L}$ & 0.45 & $84 \pm 10^{*}$ & $63 \pm 12$ & 0.38 \\
\hline NA & $3.7 \pm 0.9 \mu \mathrm{mol} / \mathrm{L} \dagger$ & $2.2 \pm 1.3 \mu \mathrm{mol} / \mathrm{L}$ & 0.78 & $44 \pm 10 \ddagger$ & $52 \pm 15$ & 0.68 \\
\hline ET-1 & $2.3 \pm 0.5 \mathrm{nmol} / \mathrm{L} \S$ & $2.2 \pm 0.9 \mathrm{nmol} / \mathrm{L}$ & 0.95 & $134 \pm 27 \|$ & $182 \pm 26$ & 0.11 \\
\hline $\mathrm{PGN}_{2 \alpha}$ & $\mathrm{NC}$ & $\mathrm{NC}$ & $\mathrm{NC}$ & $>41 \pm 15 \pi$ & $>70 \pm 17$ & 0.26 \\
\hline \multicolumn{7}{|c|}{ Aortic wall } \\
\hline 5-HT & $\mathrm{NC}$ & $\mathrm{NC}$ & $\mathrm{NC}$ & $<-30 \pm 10^{*}$ & $-5 \pm 9$ & 0.06 \\
\hline NA & $>5.1 \pm 1.4 \mu \mathrm{mol} / \mathrm{L} \dagger$ & $>2.1 \pm 0.6 \mu \mathrm{mol} / \mathrm{L}$ & 0.21 & $>93 \pm 18 \ddagger$ & $>73 \pm 18$ & 0.46 \\
\hline ET-1 & $>19 \pm 4 \mathrm{nmol} / \mathrm{L} \S$ & $>44 \pm 23 \mathrm{nmol} / \mathrm{L}$ & 0.36 & $>85 \pm 9 \|$ & $>82 \pm 24$ & 0.56 \\
\hline $\mathrm{PGF}_{2 \alpha}$ & $\mathrm{NC}$ & $\mathrm{NC}$ & $\mathrm{NC}$ & $>78 \pm 91$ & $>43 \pm 8$ & 0.20 \\
\hline
\end{tabular}

Values are mean plus or minus standard error of mean. $p$ Values are for differences between means. NA, Noradrenaline; NC, not calculated because the maximal response was not reached.

${ }^{*} p=0.001$.

$\dagger p=0.87$.

$\neq p=0.12$.

$\S p=0.03$.

$\| p=0.06$.

I $p=0.07$.

we observed morphologic changes (Fig. 6, $A$ and $B$ ) that were interpreted as signs of reversible damage: swelling of mitochondria and endoplasmic reticulum. Irreversible damage, for example that indicated by disruption of membranes, was not seen.

\section{Discussion}

In this study we showed that intact porcine aortic valve leaflets respond with contraction to various vasoactive compounds. Moreover, we were able to measure these properties in a quantitative manner. Cryopreservation of the valve leaflets resulted in a considerable reduction of contraction and induced a number of morphologic changes on electron-microscopic analysis. However, after cryopreservation, the valve leaflets still responded to the compounds tested. When expressed as a percentage of the response to potassium, the response to 5-HT, nor- 

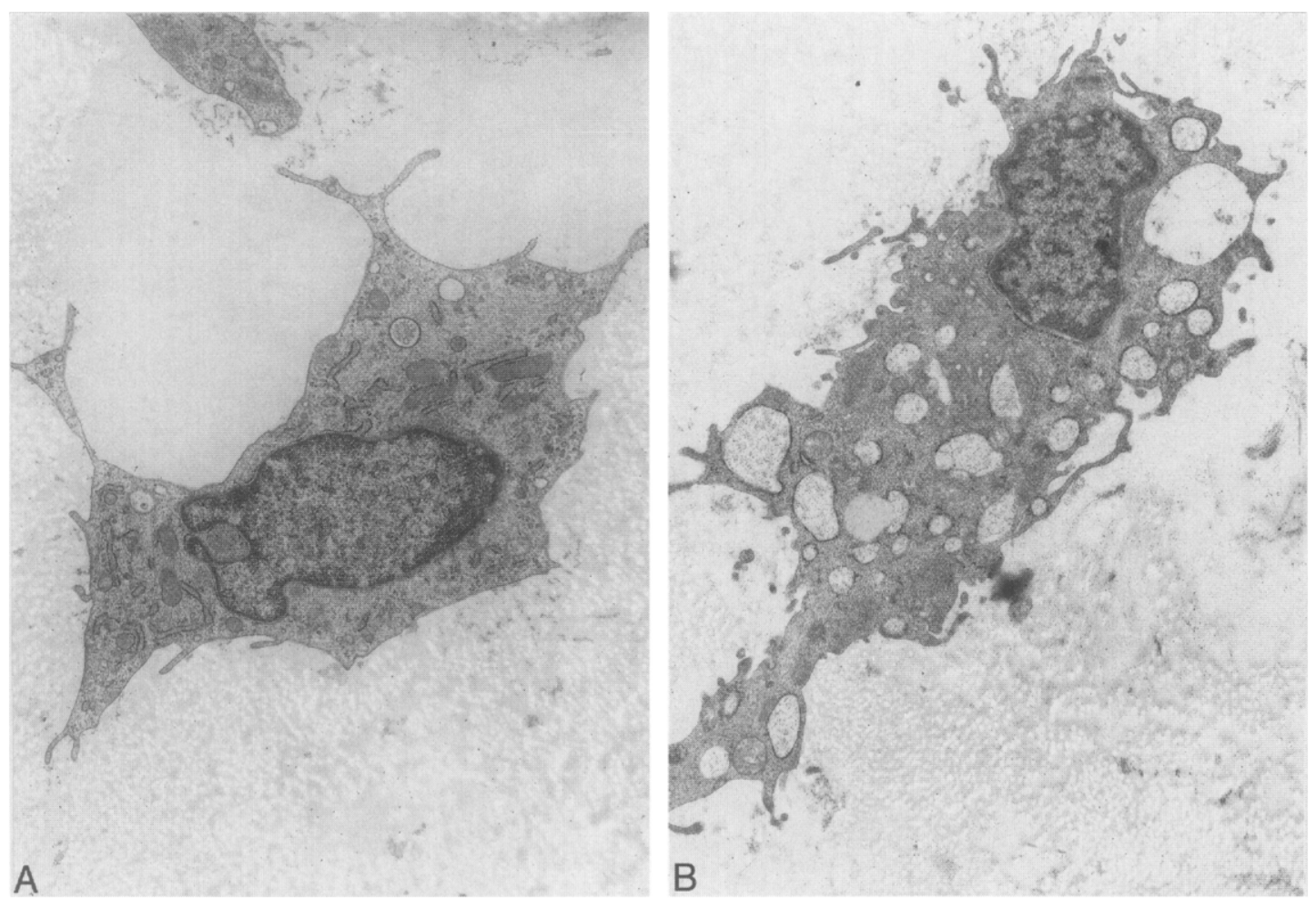

Fig. 6. A, Electron microscope picture of myofibroblasts in fresh semilunar leaflet (original magnification $\times 7000$ ). Throughout cytoplasm fine actin fibrils are visible. B, Myofibroblast in cryopreserved leaflet showing swelling of mitochondria and endoplasmic reticulum. These morphologic changes are considered to be reversible (original magnification $\times 7000$ ).

adrenaline, ET-1, and $\mathrm{PGF}_{2 \alpha}$ remained unchanged with respect to $\mathrm{E}_{\mathrm{MAX}}$ and $\mathrm{EC}_{50}$ values.

The presence of $\alpha$-smooth muscle actin filaments in aortic valve leaflets was documented ${ }^{16}$ long before the assessment of the dynamic contractile properties of strips of atrioventricular (tricuspid) valve leaflets $^{11}$ and isolated interstitial cells from aortic valve leaflets. ${ }^{12}$ A smooth muscle system was described for aortic valves, which consists of small bundles arranged in a radial way in the proximal one third of all three semilunar leaflets. ${ }^{17}$ Others found that the interstitial cells of atrioventricular and sigmoid valve leaflets contain actomyosin and are typically elongated in shape, with many long, slender processes establishing a three-dimensional network. ${ }^{11}$ The physiologic significance of the contractile properties of these cells was proposed to lie in rearranging and packing of (new) collagen fibers into bundles. ${ }^{18}$ Apart from these contractile capacities, leaflet fibroblasts are also able to synthesize matrix proteins. ${ }^{6-10}$ This leaflet interstitial cell population, which can express characteristics of both smooth muscle cells and fibroblasts, has been designated "myofibroblasts"12, 19 and these dual characteristics ${ }^{12}$ comply very well with observations in fibroblasts in other tissues, which can also exhibit heterogenic phenotypic features. ${ }^{20}$

We observed only weak correlations between the weight of the samples and the contractile response to $100 \mathrm{mmol} / \mathrm{L} \mathrm{K}^{+}$and between the potassiuminduced responses of the fresh and cryopreserved tissue samples. Variability in the density of contractile elements throughout a single leaflet and between leaflets of a valve may have played a role.

The results obtained in our organ bath experiments would indicate a difference between the contractile elements in valve leaflets (that is, interstitial cells/myofibroblasts) and aortic wall (that is, smooth muscle cells), considering the contractile response to 5-HT seen in valve leaflets versus the relaxant response observed in aortic wall. This difference in response may also be caused by the presence of different 5-HT receptors coupled to different second messenger systems. ${ }^{21}$ On the other hand, we cannot 
rule out functional involvement of 5-HT receptors on the endothelium, which may be responsible for relaxation. ${ }^{22}$ In this study we adhered to preparation methods used in the procedures for human valves and made no attempts to control the presence or absence of endothelium. In addition, it was shown that smaller concentrations of ET-1 were necessary to evoke a contractile response in valves than in aortic strips, as evidenced by the difference in $\mathrm{EC}_{50}$ values. However, we previously showed that, in particular for a large molecule like ET-1, the observed $\mathrm{EC}_{50}$ value may be affected by the architecture of the tested tissue, which leads to differences in penetration of the agonist. ${ }^{23}$ Indeed the thin aortic valve leaflet may be penetrated by ET-1 more easily than the robust aortic wall. For some agonists it may appear, from Figs. 2 to 5 , that different results were obtained before and after cryopreservation. However, these differences were not consistent for both valve leaflets and aortic wall and are considered of low significance.

The reduction in contraction of aortic wall strips after cryopreservation was considerably larger in our material than in human pulmonary arteries (reduced to $76 \%$ ) $^{24}$ and canine basilar arteries (reduced to $69 \%$ ), ${ }^{25}$ but comparable to porcine coronary arteries (reduced to $20 \%$ ). ${ }^{26}$ Of significance here is the preservation protocol used in our study, which primarily aimed at optimal preservation of matrix protein synthesis in the valve leaflets, ${ }^{7}$ not at optimal contractile responses of the aortic wall. Furthermore, differences between studies in species, cryoprotective agents, freezing and thawing rates (for example, as a result of a larger tissue sample), storage temperatures, and storage duration may have played a role.

The electron microscope photographs of myofibroblasts showed the morphologic damage that accompanied the reduction in the contractile capacity after a freeze-thaw cycle. The cells did not appear to be irreversibly damaged after our preservation protocol. A reduction in contraction could be explained by depletion of energy stores. ${ }^{27,28}$ Enzyme activity seems unchanged after cryopreservation. ${ }^{29}$ The exact interrelationship, however, between contraction, energy stores, and enzyme activity and between changes in these parameters can only be assessed in a combined study.

Quantitative assessment of functional viability of tissues that are to be transplanted is crucial for a sensible interpretation of follow-up studies on the performance of these tissues after implantation. The outcome of these combined studies allows for selec- tion of those harvesting and preservation techniques that render donor valves that have the best clinical performance. Fresh vascular tissues such as arteries $^{24-26}$ and veins ${ }^{25,30}$ possess the capacity to contract or relax in response to various compounds. These qualities are currently being used as a measure for functional viability of these tissues before and after preservation procedures. Because the fresh, vital population of interstitial cells of valve leaflets possesses dual capacities (protein synthesis, contraction), one can test either quality to assess the functional viability of a leaflet. The present study suggests that also in valve leaflets contractility can be tested in a quantitative way. Further studies are essential in determining the pathophysiologic/physiologic role of contraction of interstitial cells in semilunar valve leaflets.

The provision of a generous supply of porcine hearts by the Rotterdam Porcine Slaughterhouse is gratefully acknowledged. We thank Mrs. Z. Aghai and Mrs. C. van Tricht for their assistance during cryopreservation of the specimens.

\section{REFERENCES}

1. O'Brien MF, Stafford G, Gardner MAH, et al. The viable cryopreserved allograft aortic valve. J Card Surg 1987;1:15367.

2. Angell WW, Angell JD, Oury JH, Lamberti JJ, Grehl TM. Long-term follow-up of viable frozen aortic homografts. J Thorac Cardiovasc Surg 1987;93:815-22.

3. Grunkemeier GL, Bodnar E. Comparison of structural failure among different "models" of homograft valves. J Heart Valve Dis 1994;3:556-60.

4. Fischlein T, Schütz A, Uhlig A, et al. Integrity and viability of homograft valves. Eur J Cardiothorac Surg 1994;8:425-30.

5. Crescenzo DG, Hilbert SL, Barrick MK, et al. Donor heart valves: electron microscopic and morphometric assessment of cellular injury induced by warm ischemia. $\mathrm{J}$ Thorac Cardiovasc Surg 1992;103:253-8.

6. Al-Janabi N, Gibson K, Rose J, Ross DN. Protein synthesis in fresh aortic and pulmonary valve allografts as an additional test for viability. Cardiovase Res 1973;7:247-50.

7. Kamp van der AWM, Visser W, Dongen van JM, Nauta J, Galjaard H. Preservation of aortic heart valves with maintenance of cell viability. J Surg Res 1981;30:47-56.

8. Hu J-F, Gilmer L, Hopkins R, Wolfinbarger L. Effects of antibiotics on cellular viability in porcine heart valve tissue. Cardiovase Res 1989;23:960-4.

9. Brockbank KG, Dawson PE. Cytotoxicity of amphotericin B for fibroblasts in human heart valve leaflets. Cryobiology 1993;30:19-24.

10. Brockbank KGM, Carpenter JF, Dawson PE. Effects of storage temperature on viable bioprosthetic heart valves. Cryobiology 1992;29:537-42.

11. Filip DA, Radu A, Simionescu M. Interstitial cells of the heart valves possess characteristics similar to smooth muscle cells. Circ Res 1986;59:310-20. 
12. Messier RH, Bass BL, Aly HM, et al. Dual structure and functional phenotypes of the porcine aortic valve interstitial population: characteristics of the leaflet myofibroblast. J Surg Res 1994;57:1-21.

13. Thijssen HJM, Bos E, Konertz W, van Suylen RJ, de By TMMH. Kryokonservierung humaner Spenderherzklappen in der Herzklappenbank in Rotterdam. Z Herz Thorax Gefasschir 1992;6:49-55.

14. De Lean A, Munson PJ, Rodbard D. Simultaneous analysis of families of sigmoidal curves: application to bioassay, radioligand assay and physiological dose-response curves. Am J Physiol 1978;235:E97-E102.

15. Crescenzo DG, Hilbert SL, Messier RH, et al. Human cryopreserved homografts: electron microscopic analysis of cellular injury. Ann Thorac Surg 1993;55:25-31.

16. Becker CG, Murphy GE. Demonstration of contractile protein in endothelium and cells of the heart valves, endocardium, intima, atherosclerotic plaques, and Aschoff bodies of rheumatic heart disease. Am J Pathol 1969;55:1-37.

17. Bairati A, DeBiasi S. Presence of a smooth muscle system in aortic valve leaflets. Anat Embryol 1981;161:329-40.

18. Harris A, Stopak D, Wild P. Fibroblast traction as a mechanism for collagen morphogenesis. Nature 1981;290:249-51.

19. Gabbiani $G$, Ryan GB, Majno G. Presence of modified fibroblasts in granulation tissue and their possible role in wound contraction. Experientia 1971;27:549-50.

20. Schmitt-Gräff A, Desmoulière A, Gabbiani G. Heterogeneity of myofibroblast phenotypic features: an example of fibroblastic cell plasticity. Virchows Arch 1994;425:3-24.

21. Hoyer D, Clarke DE, Fozard JR, et al. International Union of Pharmacology classification of receptors for 5-hydroxytryptamine (serotonin). Pharmacol Rev 1994;46:157-203.
22. Cohen RA, Shepherd JT, Vanhoutte PM. 5-Hydroxytryptamine can mediate endothelium-dependent relaxation of coronary arteries. Am J Physiol 1983;245:H1077-80.

23. Bax WA, Aghai Z, van Tricht CLJ, Wassenaar C, Saxena PR. Different endothelin receptors involved in endothelin-1 and sarafotoxin S6B-induced contractions of the human isolated coronary artery. Br J Pharmacol 1994;113:1471-9.

24. Ellis P, Müller-Schweinitzer E. Maintenance of functional activity of human pulmonary arteries after cryopreservation. Br J Pharmacol 1991;103:1377-80.

25. Müller-Schweinitzer E, Tapparelli C. Pharmacological studies on frozen stored canine saphenous veins and basilar arteries. Naunyn Schmiedebergs Arch Pharmacol 1986;332:74-8.

26. Schoeffter P, Müller-Schweinitzer E. The preservation of functional activity of smooth muscle and endothelium in pig coronary arteries after storage at $-190^{\circ} \mathrm{C}$. J Pharm Pharmacol 1990;42:646-51.

27. Messier RH, Domkowski PW, Aly HM, et al. High energy depletion in leaflet matrix cells during processing of cryopreserved cardiac valves. J Surg Res 1992;52:483-8.

28. Domkowski PW, Messier RH, Crescenzo DG, et al. Preimplantation alteration of adenine nucleotides in cryopreserved heart valves. Ann Thorac Surg 1993;55:413-9.

29. Lang SL, Giordano MS, Cardon-Cardo C, Summers BD, Staiano-Coico L, Hajjar DP. Biochemical and cellular characterization of cardiac valve tissue after cryopreservation or antibiotic preservation. J Thorac Cardiovasc Surg 1994;108: 63-7.

30. Brockbank KGM, Carpenter JF, Schwartz LB, Nardiello $C$, Hagen PO. Smooth muscle function in short- and long-term stored cryopreserved veins. Vasc Surg 1992;26: 116-22. 